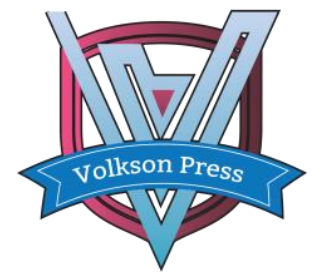

Contents List available at VOLKSON PRESS

Economics \& Management Innovations(EMI)

DOI : http://doi.org/10.26480/icemi.01.2017.111.112

\title{
Analysis of legal remedies for wrongful dismissal
}

\section{Yanli Yu}

Hongshan district, Wuhan city, Hubei province, PRC.

1565923816@qq.com

This is an open access article distributed under the Creative Commons Attribution License, which permits unrestricted use, distribution, and reproduction in any medium, provided the original work is properly cited.

\section{ARTICLE DETAILS}

\section{Article History:}

Received 02 october 2017

Accepted 06 october 2017

Available online 11 october 2017

\section{Keywords:}

wrongful dismissal, legal remedy, reinstatement, recompense.

\section{ABSTRACT}

According to the provisions of ILO Convention No. 158th, when the employer fired the worker, they must have the right reason and follow due process. If not, it is necessary for them to bear the legal liability. In terms of Chinese current legal system, there is no slip law on employer's unjust dismissal liability, only in The Labor Contract Law are there relevant provisions. But it is, in fact, still not enough to protect the legitimate rights and interests of workers. Accordingly the paper proposes some revision suggestions on this provision, based on the analysis of relevant Chinese laws and regulations, as well as the judicial data.

\section{Introduction}

According to the ILO conventions and legislation in many countries, the employer shall not illegal dismissal of workers. Chinese relevant laws and regulations, detrimental to operate, did not consider the workers age, the cost of living and other factors. We should combine with the reality, aim at the deficiency, perfect the relevant legislation, establish the improper legal relief system which has maneuverability and can effectively protect the interests of employees.

\section{Chinese laws about unjust dismissal}

So far, there is no special rules for wrongful dismissal protection in China, which measures are mainly embodied in The Labor Contract Law. The provisions of the 48th act:If the employer illegally discharges the employee, the person who is fired has the right to choose the remedy, reinstatement or compensation. When the fired required to continue to perform the labor contract, the employer shall continue to perform the contract in the event of performance unless the performance cannot be continued;If the financial compensation is required, the amount of compensation shall be calculated according to The Labor Contract Law No. 87th, which stipulates that the economic compensation shall be twice as much as recompense.

\section{Reflection on the legal liability of wrongful dismissal}

\subsection{Recent judicial information about wrongful dismissal system in China}

In order to understand the law of unjust dismissing in Chinese judicial trial, following data were collected from the China referee instrument network in May 15, 2017. The databases, isolated from the Chinese referee file statistics from 2010 to 2017 May, is divided into two parts: One is about the proportion of unfair dismissal disputes in labor correction; Another is percentage about employees requesting reinstatement in the wrongful dismissal, including different kinds of trial. There are 223,140 copies of the judgment involving the labor dispute. Among them, The Labor Contract Law (forty-eighth) was quoted in the judgment, that is, 6,047 cases, accounting for $2.710 \%$. In the case of unjust discharge disputes, there are 1,936 copies of the continued performance, accounting for $32.016 \%$ of the total, the specific data are as follows:

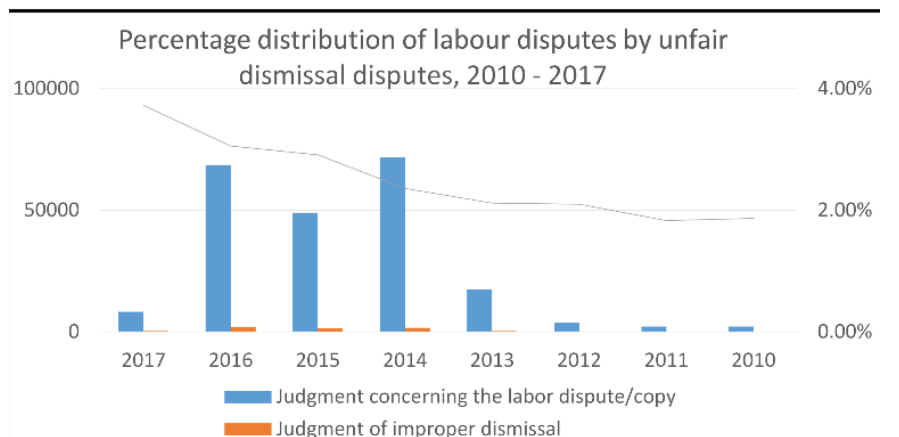

Figure 1:2010 - 2017 Percentage distribution of labor disputes in unfair dismissal disputes



Figure 2:2010-2017 Percentage distribution about employees requesting reinstatement in the wrongful dismissal

\section{2 the illustration of judicial date in China}

As the figure 1 show, the total volume of unjust dismissal disputes, in the past seven years, is increasing. And the proportion in labor disputes is on rising. The Labor Contract Law (forty-eighth) should consequently be adjusted so as to meet the needs of a pluralistic society. Besides the conclusion, that more and more sacked worker are desired to be reinstated, should be drawn from the figure 2 . Admittedly, only a tiny minority achieve their goals. The main reason of the phenomenon is that the economic 
compensation for wrongful dismissal of staff is unable to meet the damage, and the continue to fulfill the contract provisions appears uncompatible, resulting in unfair trail. Therefore we can conclude that the remedy for wrongful dismissal is too one-size-fits-all, and that continuing to fulfill the labor contract is less rigorous, and that the calculation method of economic compensation is too simple.

\section{Improving the institution of wrongful dismissal in China}

\subsection{Distinguish different types of wrongful dismissal}

In violation of procedures for wrongful dismissal, the employer's behavior is invalid as the main remedy. The employer acts against the due process clause, does not violate the substantive requirements, and labor shall be responsible for deposition, so there is no need for additional compensation in addition to the economic recompense to employees. While the employer in breach of the procedure prescribed by the law dismisses the worker, leading to the employment crisis workman have unexpected. It's a better way to invalidate the dismissal behavior, absolutely and initial. The employee isn't fired from the beginning. Employee absenteeism should be blamed for improper act from employer. So the employer may choose to have the employee re-work or continually dismiss him.

At the time of unjustified dismissal of violating substantive elements, employees can take a variety of remedies. Because the position is an important foundation for people's life, employee benefits should not be stripped. Laid-off workers, of course, can request for reinstatement or compensation. The court should combine the objective situation of the employing unit to judge. If reinstatement is absolutely unable to perform, sufficient compensation must be given to the sacked labor. At the same time, the unemployed should also have the right to choose financial compensation, which consists of restitution and recompense.

Antisocial dismissal, or prohibited dismissal, refers to dismissing for reasons of discrimination, retaliation, and other reasons. Specifically, the reasons for dismissal include age, sex, belief, racial discrimination, and reprisal for the participation of workers in trade union organizations. The employing unit adopts an anti-social mode of dismissal, which has a high degree of concealment, indicating that contradiction between labor and capital is extremely acute. Resumption of the original employment relationship is not appropriate for employees. Meanwhile, the employing unit who disregards the authority of the law should be given strict punishment. Therefore, a high penalty system should be adopted to show the punishment and deterrent effect.

\subsection{Adopting the remedy of reinstatement}

Because of the unequal status of the two parties, employees as a disadvantaged party should have the right to relief. After finding that the employer has violated the law, the employee, unless the objective situation does not allow or the employer categorically refuses, may choose resumption of labor relations or economic compensation, which should be supported. Meantime, balancing labor and capital is the result of market regulation. If limiting it, it will be harmful to the market to play the invisible hand. Therefore, employers as a rational side in market, for team harmony, cultural construction and other reasons, expelling workers is logical. It's reasonable for employers to refuse to resume their post after improperly dismissing their employees, but they need to pay for their active. Since the relief effect of reinstatement is best, execution is the most demanding, it's more appropriate to use positive examples than negative. Specifically, only when the employment parties have reasonable trust, the contract is able to be performed, the employer cost is reasonable, the mutually agree conditions, reinstatement will play a fundamental relief role.

\subsection{Reforming the current compensation system}

Borrowing the design idea of British compensation, and combining with the current legal provisions of China, economic compensation should include recompense, restitution, anti social penalties. Recompense is an unemployment benefit of the laid-off workers, which is the reasonable obligation of the employing unit to unilaterally terminate the labor contract when the contract is being performed. Restitution is the loss compensation that the wrongfully dismissed workers can claim. Restitution should be equal that the expected benefit at the time of signing contract minus the earnings from the year of work. Punitive compensation is the economic sanctions imposed on employers by employing units to dismiss employees for anti - social reasons to enable employees to obtain additional compensation. Three types of economic compensation may overlap. Besides the ceiling on compensation should be established in accordance with the principle of proportionality to prevent the abuse of power by the fire.

Conclusion

On the basis of judicial data, the article analyzes the existing defects about improper dismissal of legal relief system, and put forward suggestions, like distinguishing different types of wrongful dismissal, adopting the remedy of reinstatement, reforming the current compensation system, to solve the social practical problem of abuse of dismissal right by employing unit from the legal perspective.

\section{Acknowledgement}

I would like to express my gratitude to all those who helped me during the writing of this thesis, especially from Ms.Xia Qian, who has offered me valuable suggestions.

\section{References}

[1] Li Zhuqing: Research on the legal relief system for wrongful dismissal (master's degree thesis in Liaoning University.2015)

[2] He Dongshan: Study on the protection of the employment rights of vulnerable groups in the new legal environment Central South University press.2013(8)162 - 182

[3] Shen Tong Xian. Perfecting the relief measures of .2012 in China law of unfair dismissal laws (6):99 112

[4] Zhang Huagui: Labor contract law, Tsinghua University press, 2011 (8), $227-241$

[5] See,Williams Kevin and David Lewis(1981), The Aftermath of Tribunal Reinstatement and Re-engagement, Department of Employment Research, 23

[6] Cheng Yanyuan: a comparative analysis of the system of dismissal in the United States and Britain. Proceedings of the Chinese people's law, 2003(2), 131

[7] W ducz. Labor law. translated by Zhang Guowen. Beijing: Law Press, 2005.

[8] Huang Gang. New theory of labor law, China University of Political Science and Law press, 2003.

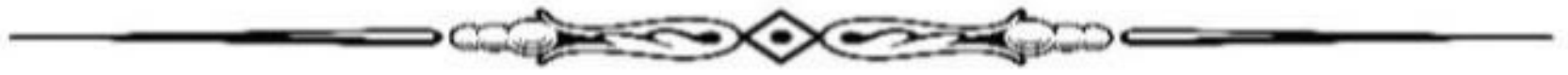

